\title{
Pembinaan terhadap Narapidana Wanita Hamil di Lembaga Pemasyarakatan Perempuan (LPP) Kelas II B Jambi
}

\author{
Elvi Alfian A \\ Fakultas Syariah UIN STS Jambi \\ Correspondence email: elvialfian23@gmail.com
}

\begin{abstract}
Abstrak. Pada dasarnya hak antara narapidana perempuan dengan narapidana pria adalah sama, hanya dalam hal ini karena narapidanannya adalah wanita maka ada beberapa hak yang mendapat perhatian khusus dibanding narapidana pria. Narapidana wanita tidak hanya dibatasi hak-haknya seperti Narapidana pada umumnya, tetapi juga mengalami kesulitan ketika harus menghadapi keadaan-keadaan yang menjadi kodratnya sebagai seorang perempuan. Tujuan penelitian ini adalah: a) Untuk mengetahui bagaimana sistem pembinaan terhadap narapidana wanita yang hamil di Lembaga Pemasyarakatan Perempuan kelas II B Jambi; b) Untuk mengetahui apa saja faktor penghambat dari pembinaan terhadap narapidana wanita yang hamil di Lembaga Pemasyarakatan Perempuan kelas II B Jambi dan c) Untuk mengetahui upaya apa yang dapat dilakukan oleh petugas Lembaga Pemasyarakatan dalam mengatasi adanya faktor penghambat dari pembinaan terhadap narapidana wanita yang hamil di Lembaga Pemasyarakatan Perempuan kelas II B Jambi. Metode penelitian adalah pendekatan yuridis empiris. Pendekatan yuridis empiris dalam penelitian ini maksudnya adalah bahwa dalam menganalisis permasalahan dilakukan dengan cara memadukan bahan-bahan hukum (yang merupakan data sekunder) dengan data primer yang diperoleh di lapangan yaitu tentang pembinaan narapidana wanita yang hamil di lembaga permasyarakatan Perempuan kelas II B Jambi. Sesuai dengan tema, maka penelitian ini menggunakan metode kualitatif deskriptif. Kesimpulan penelitian ini adalah Pembinaan terhadap Narapidana wanita hamil di Lembaga Pemasyarakatan Perempuan Kelas II B Jambi tetap disamakan dengan pembinaan Narapidana wanita lain pada umumnya, terdapat dua pembinaan yang diterapkan di LPP Kelas II B Jambi, yaitu Pembinaan Kepribadian dan Pembinaan Kemandirian. Narapidana wanita hamil mendapatkan keringanan dari pihak LPP untuk tidak melakukan pekerjaan yang beratberat seperti rutinitas piket kamar, kegiatan senam disetiap hari sabtu, gotong royong ataupun kegiatan lain yang membahayakan kondisi kandungan ataupun Ibunya. Dapat dikatakan bahwa Pembinaan yang diberikan pihak LPP terhadap Narapidana wanita yang hamil sesuai dengan yang penulis teliti saat ini, untuk pemenuhan hak-haknya belum terpenuhi secara maksimal dikarenakan dari faktor kurangnya dana.
\end{abstract}

Kata Kunci: narapidana; wanita hamil; lembaga pemasyarakatan perempuan (LPP)

\begin{abstract}
Basically the right between female inmates and male inmates is the same, only in this case because the inmate is a woman then there are some rights that get special attention than male inmates. Female inmates are not only limited to their rights as inmates in general, but also have difficulty when facing the circumstances that become their nature as a woman. The purpose of this study was: a) To find out how the system of coaching female inmates who are pregnant in the Class II B Jambi Women's Correctional Institution; b) To find out what are the inhibition factors of coaching female inmates who are pregnant in the Women's Correctional Institution class II B Jambi and c) To find out what efforts can be made by correctional officers in overcoming the inhibition factor of coaching female inmates who are pregnant in the Women's Correctional Institution class II $B$ Jambi. The research method is an empirical juridical approach. Empirical juridical approach in this study means that in analyzing the problem is done by combining legal materials (which are secondary data) with primary data obtained in the field that is about the development of pregnant female inmates in the Class II B Jambi Women's Society. In accordance with the theme, this research uses descriptive qualitative methods. The conclusion of this study is coaching of pregnant female inmates in The Class II B Jambi Women's Correctional Institution remains equated with the coaching of other female inmates in general, there are two coachings applied in the Class II B Jambi LPP, namely Personality Coaching and Self-Reliance Coaching. Pregnant female inmates get waivers from the LPP not to do heavy work such as room picket routines, gymnastics activities every Saturday, gotong royong or other activities that endanger the condition of the womb or mother. It can be said that the guidance provided by the LPP to pregnant female inmates in accordance with the author's current meticulous, for the fulfillment of his rights has not been fulfilled to the maximum due to the lack of funds.
\end{abstract}

Keywords: inmate; pregnant women; women's correctional institution (LPP)

\section{PENDAHULUAN}

Negara Indonesia yang memberlakukan KUHP sebagai sumber utama hukum pidana telah merinci jenisjenis pidana sebagaimana dirumuskan dalam pasal 10 KUHP, pidana dibedakan menjadi dua kelompok. Pertama, pidana pokok yang meliputi hukum mati, penjara, kurungan, denda dan pidana tutupan. Kedua pidana tambahan yang terdiri dari pencabutan hak-hak tertentu, perampasan barang-barang tertentu dan pengumuman keputusan hakim dalam menjatuhkan hukuman terhadap pelaku kejahatan.${ }^{1}$ Dengan lahirnya pidana maka hilanglah kemerdekaan, hukum tersebut

1 Kitab Undang-Undang Hukum Pidana Pasal 10 Tentang Pidana 
berubah menjadi pidana penjara selama batas waktu yang ditentukan oleh hakim.

Namun sejak tahun 1964 pembinaan bagi narapidana wanita berubah. Yaitu dari sistem kepenjaraan menjadi sistem pemasyarakatan dengan tujuan agar mantan narapidana kembali menjadi masyarakat yang baik dan diterima di masyarakat. ${ }^{2}$ Seperti yang terdapat dalam Undang-Undang Nomor 12 Tahun 1995 dalam pasal (2) yang berbunyi :

"Agar warga Binaan Pemasyarakatan menjadi manusia seutuhnya yang dapat aktif berperan dalam pembangunan dan dapat hidup secara wajar sebagai warga yang baik dan bertanggung jawab". ${ }^{3}$

Itulah tujuan dari adanya pembinaan terhadap Narapidana atau Warga Binaan Pemasyarakatan, bahkan mereka semua selama menjadi Narapidana banyak yang mereka ketahui dari segi kerajinan, keagamaan dan pekerjaan lainnya ada didalam LAPAS. Semua itu bertujuan agar si Narapidana ketika sudah habis masa tahanan atau ketika sudah keluar dari LAPAS mereka bisa diterima kembali di masyarakat.

Begitu pula institusinya yang semula disebut sebagai Rumah Penjara dan Rumah Pendidikan Negara berubah menjadi Lembaga Pemasyarakatan yang ditopang dengan Undang-Undang Nomor 12 Tahun 1995. Dan pada saat ini tempat bagi Narapidana wanita di Kelas II B Muaro Jambi telah resmi diberi nama Lembaga Pemasyarakatan Perempuan (LPP).

Di negara berkembang seperti Indonesia masalah pembinaan kehidupan berbangsa dan bernegara yang beradab sering terabaikan. Bahkan sebuah ideologi sering tergantikan oleh kekuatan ekonomi yang cenderung lebih berperan. Sering manusia salah jalan dan melakukan tindakan diluar aturan yang berlaku demi mendapatkan ekonomi yang layak. Selain itu, kecenderungan peningkatan kesejahteraan dan taraf hidup membuat semakin beragam masalah dalam masyarakat, seperti kejahatan, ataupun perbuatan yang melanggar hukum. ${ }^{4}$

Situasi tidak terduga berada pada waktu dan tempat yang salah atau karna kekhilafan seseorang sehingga harus kehilangan kemerdekaannya dengan menjadi narapidana. Bicara tentang narapidana, salah satunya ialah narapidana wanita. Keterlibatan wanita sebagai pelaku kriminalitas memang bukan hal yang baru, walaupun keterlibatan ini relative lebih kecil dibandingkan pria, kriminalitas dilakukan seorang wanita karena beberapa alasan, seperti yang sudah

${ }^{2}$ Dwidja Priyatno, Sistem Pelaksanaan Pidana Penjara di Indonesia, Cetakan ke 3, (Bandung : Refika Aditama, 2009), hlm. 106

3 Undang-Undang Dasar RI Nomor 12 Tahun 1995 Tentang Pemasyarakatan Pasal 2

${ }^{4}$ Lily Lastriana Dewi, Jurnal, Pembinaan Narapidana Wanita yang Mempunyai Anak Balita atau dalam Keadaan Mengandung di Lembaga Pemasyarakatan, Universitas Atma Jaya Yogyakarta, fakultas hukum, 2014, hlm. 4 dijelaskan diatas, salah satu diantara penyebabnya adalah dari faktor perekonomian yang kurang memadai.

Di mata hukum yang berbuat kriminal dianggap bersalah dan harus dipidana walaupun ia seorang wanita. Hal ini sesuai dengan Undang-Undang Dasar Republik Indonesia Tahun 1945 pasal 27, yang sudah diamandemen dari 2 ayat menjadi 3 ayat, bahwa semua warga negara sama kedudukannya termasuk wanita. Seorang Narapidana yang sedang menjalani hukuman didalam LAPAS mereka perlu mendapatkan perhatian, terutama dalam pemberian hak asasinya sebagai seorang manusia. Narapidana juga harus diayomi hak-haknya meskipun mereka telah melanggar hukum. Dalam UU No. 12 Tahun 1995 Tentang Pemasyarakatan Pasal 14 ayat (1), secara tegas dinyatakan bahwa terpidana berhak .5

1. Melakukan ibadah sesuai dengan agama atau kepercayaannya

2. Mendapat perawatan baik rohani ataupun jasmani

3. Mendapat pendidikan dan pengajaran

4. Mendapat pelayanan kesehatan dan makan yang layak

5. Menyampaikan keluhan

6. Mendapat bahan bacaan dan mengikuti siaran media massa lainnya yang tidak dilarang

7. Mendapatkan upah atau premi atas pekerjaan yang dilakukan

8. Menerima kunjungan keluarga, penasehat hukum, atau orang tertentu lainnya

9. Mendapat pengurangan masa pidana

10.Mendapatkan kesempatan berasimilasi termasuk cuti mengunjungi keluarga

11. Mendapatkan kebebasan bersyarat

12. Mendapatkan cuti menjelang bebas

Pada dasarnya hak antara narapidana perempuan dengan narapidana pria adalah sama, hanya dalam hal ini karena narapidanannya adalah wanita maka ada beberapa hak yang mendapat perhatian khusus dibanding narapidana pria. ${ }^{6}$ Contohnya seorang perempuan akan mengalami siklus menstruasi sehingga masalah kehigienisan menjadi suatu yang perlu mendapatkan perhatian lebih. Selain itu, Narapidana wanita yang sedang hamil atau dalam keadaan melahirkan juga membutuhkan perawatan yang khusus untuk menjamin kesehatan ibu dan anak. Ketika anak itu pun lahir, perempuan jugalah yang mampu menyusui. Jadi disitulah Narapidana wanita perlu mendapatkan perhatian yang khusus baik menurut Undang-Undang maupun petugas Lembaga Pemasyarakatan diseluruh wilayah Indonesia.

5 Undang-Undang No. 12 Tahun 1995 Tentang Pemasyarakatan Pasal 14

6 Fita Lisani, Skripsi, Pembinaan Terhadap Narapidana Wanita di Lembaga Pemasyarakatan Anak dan Wanita di Muara Bulian Menurut Hukum Pidana Islam, Mahasiswa Fakultas Syari'ah Institut Agama Islam Negri Sultan Thaha Saifuddin Jambi, 2015, hlm. 3 
Pengaturan mengenai pelaksanaan hak narapidana wanita tertuang didalam peraturan pemerintah Nomor 32 Tahun 1999 tentang Syarat dan Tata Cara Pelaksanaan Hak Warga Binaan Pemasyarakatan. Dimana dalam pasal 20 mengatur perlindungan terhadap narapidana wanita, yaitu : ${ }^{7}$

1. Narapidana dan anak didik pemasyarakatan yang sakit, hamil dan menyusui berhak mendapat makanan tambahan sesuai dengan petunjuk dokter.

2. Makanan tambahan juga diberikan kepada narapidana yang melakukan pekerjaan jenis tertentu.

3. Anak dari narapidana wanita dibawa kedalam Lembaga Pemasyarakatan ataupun yang lahir di Lembaga Pemasyarakatan dapat diberi makanan tambahan atas petunjuk dokter, paling lama sampai berumur 2 tahun.

4. Dalam hal anak sebagaimana dimaksud dalam ayat 3 telah mencapai umur 2 tahun, harus diserahkan kepada sanak keluarganya.

5. Untuk kepentingan kesehatan anak, kepala Lembaga Pemasyarakatan dapat menentukan makanan tambahan.

Narapidana wanita tidak hanya dibatasi hakhaknya seperti Narapidana pada umumnya, tetapi juga mengalami kesulitan ketika harus menghadapi keadaankeadaan yang menjadi kodratnya sebagai seorang perempuan. Narapidana wanita memiliki kodrat yang berbeda dengan pria, sudah menjadi kodratnya wanita mengalami siklus menstruasi, hami, melahirkan dan menyusui yang tidak dimiliki oleh Narapidana lain. Padahal mengingat bahwa konsep yang ditumbuh kembangkan di Indonesia merupakan pembinaan dan bukan pembalas dendam (retribution), seharusnya pemerintah menaruh perhatian lebih pada kebutuhankebutuhan khusus Narapidana wanita tersebut. ${ }^{8}$

Khusus untuk Remisi, asimilasi, cuti menjelang bebas dan pembebasan bersyarat merupakan hak seorang Narapidana, baik dewasa maupun anak, sebagai Narapidana. Pelaksanaan perolehan Remisi, Asimilasi, cuti menjelang bebas dan pembebasan bersyarat tersebut diatur dalam Peraturan Pemerintah No 32 Tahun 1999 Tentang Syarat dan Tata Cara Pelaksanaan Hak Warga Binaan Pemasyarakatan. Pelaksanaan hak-hak lain narapidana wanita yang hamil dijelaskan berdasarkan kebijakan masing-masing Lembaga Pemasyarakatan, seperti :

1. Memberikan dispensasi untuk tidak mengikuti kegiatan olahraga

7 Peraturan Pemerintah No. 32 Tahun 1999 Tentang Syarat dn Tata Cara Pelaksanan Hak Warga Binaan Pemasyarakatan Pasal 20

${ }^{8}$ Achmad Fatony, https://www.researchgat.net, Efektifitas Pelaksanaan Hak-Hak Warga Binaan Perempuan dalam Mewujudkan Tujuan Pemasyarakatan : Study Kasus Rumah Tahanan Kelas II A Jakarta Timur, diakses pada selasa, 21 April 2020, Pukul 22:00 WIB
2. Memberikan dispensasi untuk tidak mengikuti kegiatan kerja bakti

3. Memberikan dispensasi terhadap kegiatan-kegiatan yang membahayakan kesehatan si ibu maupun kandungan.

Kewajiban seorang Narapidana wanita yang hamil sama dengan Narapidana lainnya yang harus dilakukan selama menjalani masa hukuman di Lembaga Pemasyarakatan Perempuan (LPP). Kewajiban tersebut diatur dalam Peraturan Mentri Hukum dan Hak Asasi Manusia RI Nomor 6 Tahun 2013 Tentang Tata Tertib Lembaga Pemasyarakatan dan Rumah Tahanan Pasal 3 yang berbunyi, Setiap Narapidana atau Tahanan wajib $:^{9}$

1. Taat menjalankan ibadah sesuai agama dan/atau kepercayaan yang dianutnya serta memelihara kerukunan beragama

2. Mengikuti seluruh kegiatan yang di programkan

3. Patuh, taat dan hormat kepada petugas

4. Mengenakan pakaian seragam yang telah ditentukan

5. Memelihara kerapian diri dan lingkungan hunian serta mengikuti kegiatan yang dilaksanakan dalam rangka kebersihan lingkungan hunian, dan

6. Mengikuti apel kamar yang dilaksanakan oleh petugas pemasyarakatan.

Kewajiban bagi Narapidana wanita yang hamil biasanya diberikan toleransi dari pihak LPP atas dasar kemanusiaan. Dimana pada masa sekarang dalam Lembaga Pemasyarakatan, suatu kewajiban yang dimiliki oleh seluruh Narapidana khususnya Narapidana wanita yang hamil tidaklah menjadi kewajiban yang harus dikerjakan, sehingga membuat seorang Narapidana wanita yang hamil tersebut merasa terbebani dan dapat berdampak terhadap kesehatan calon ibu, bayi dan janin. Namun bagi Narapidana wanita yang hamil yang diberikan toleransi dalam kewajiban bimbingan kerja, tetap wajib mengikuti aturan yang berlaku dalam LPP dan wajib patuh terhadap petugas LPP. ${ }^{10}$

Berkaitan dengan Narapidana wanita yang hamil di Lembaga Pemasyarakatan Perempuan (LPP) Kelas II B Jambi, terdapat beberapa jumlah Narapidana wanita yang hamil. Salah satu petugas mengatakan "Bahwa pada 3 (tiga) tahun yang lalu, yakni dari tahun 2017 sampai pada tahun 2019 jumlah Narapidana wanita yang hamil di Lembaga Pemasyarakatan Perempuan Kelas II B Jambi berjumlah sebanyak 5 (Lima) orang Narapidana wanita yang hamil. Dimana pada tahun 2017 sebanyak 1 (satu) orang Narapidana dan pada tahun 2019 terdapat 4

\footnotetext{
${ }^{9}$ Peraturan Pemerintah No 6 Tahun 2013 Tentang Tata Tertib Lembaga Pemasyarakatan dan Rumah Tahanan Pasal 3

10 Anita Ayu Widyastuti, Skripsi, Implementasi Hak dan Kewajiban Bagi Warga Binaan Wanita Hamil atau Menyusui dalam Menjalani Masa Hukuman di LAPAS Perempuan Kelas II B Yogyakarta, Universitas Islam Indonesia, Fakultas Hukum, 2018, hlm. 77
} 
(empat) orang Narapidana wanita yang hamil. Lima Narapidana wanita yang hamil ini terdapat 4 (Empat) Narapidana yang terjerat dalam kasus kriminal dan 1 (satu) Narapidana terjerat dalam kasus narkoba. Empat Narapidana melahirkan di Rumah Sakit dan 1 (satu) Narapidana melahirkan di Lembaga Pemasyarakatan karena tidak sempat dilarikan ke Rumah Sakit. Kemudian anak yang dilahirkan diasuh didalam Lembaga Pemasyarakatan, sampai mencapai umur 2 tahun. Jika sudah mencapai umur 2 tahun dan ternyata ibunya belum bebas sebagai seorang Narapidana, maka anak wajib diberikan kepada pihak keluarga".

Masa pemulihan seorang Narapidana pasca persalinan atau melahirkan yaitu : jika Narapidana yang melaksanakan persalinan atau melahirkan dalam keadaan normal ternyata lebih singkat dari pada melahirkan secara caesar. Pemulihan pasca persalinan secara normal berlangsung selama 6 mimggu (42 hari) atau lebih sering dikenal dengan masa nifas. Sedangkan waktu pemulihan setelah melahirkan secara caesar biasanya bekas luka jahitan akan pulih dalam waktu 6 minggu, namun untuk seluruh luka termasuk luka pada rahim biasanya akan pulih lebih lama, bisa sampai 2 tahun.

Seorang Narapidan yang telah melaksanakan persalinan atau melahirkan, dia akan mendapat perlakuan yang sama sebagaimana Narapidana lain pada umumnya. Mereka akan kembali mengikuti kegiatankegiatan yang terdapat di LPP, dan kembali melaksanakan kewajibannya sebagai seorang Narapidana wanita pada biasanya.

Hal ini menimbulkan opini apakah negara menjamin terhadap narapidana yang dalam proses mengandung tersebut dipastikan mendapat fasilitas untuk memeriksa kandungan setiap bulan dan mendapatkan jaminan fasilitas melahirkan yang memadai di dalam Lembaga Pemasyarakatan. Maka dalam hal ini narapidana wanita perlu mendapat perhatian yang khusus baik menurut Undang-Undang maupun petugas Lembaga Pemasyarakatan di seluruh wilayah Indonesia. ${ }^{11}$ Sebagaimana diatur dalam UndangUndang Nomor 12 Tahun 1995 dalam pasal (14) mengenai narapidana berhak mendaptakan fasilitas kesehatan. Sedangkan didalam sistem pembinaan narapidana wanita hamil ini tentunya Lembaga Pemasyarakatan terdapapat hambatan atau kesulitan dalam menjalankan sistem pembinaannya. Oleh karena itu, Lembaga Pemasyarakatan harus memiliki upaya atau cara tersendiri agar tidak terjadinya suatu hambatan atau kesulitan didalam menjalankan sistem pembinaan tersebut.

\section{Kerangka Teori}

Kerangka teori adalah konsep-konsep yang sebenarnya merupakan abstraksi-abstraksi dari hasil pemikiran, digunakan sebagai dasar atau kerangka acuan

${ }^{11}$ Undang-Undang RI Nomor 12 Tahun 1995 Tentang Pemasyarakatan Pasal 12 Ayat (2) yang bertujuan untuk mengadakan kesimpulan yang dianggap telah sesuai dengan suatu penelitian. ${ }^{12}$ Berdasarkan penelitian yang telah penulis angkat berkaitan dengan Pembinaan Terhadap Narapidana Wanita Hamil di Lembaga Pemasyarakatan Perempuan Kelas II B Jambi, maka digunakan teori:

\section{Teori Pemidanaan}

Teori Pemidanaan adalah proses pemberian atau penjatuhan pidana oleh Hakim yang disebut pemidanaan. Dalam teori pemidanaan dikenal tiga aliran, yaitu : Aliran Absolut, aliran Relatif dan aliran Gabungan. Selain teori tersebut adapula teori hak, dalam kasus ini seorang Narapidana diberi hak karena manusia dari berbagai lapisan kehidupan yang harus mendapat perlakuan yang sama. ${ }^{13}$

Teori Pemidanaan menjelaskan mengenai bagaimana sanksi pidana dijatuhkan kepada si pelaku semata-mata karena sipelaku telah melakukan kejahatan. Pada dasarnya dalam teori ini bertujuan untuk menegakkan tata tertib (hukum) dalam masyarakat, karena didalam pemidanaan tersebut bukan sebagai pembalasan untuk pelaku yang telah melakukan kejahatan, akan tetapi untuk mencegah agar orang tersebut tidak melakukan tindak kejahatan lagi ataupun mengulangi kejahatan yang dipernah dilakukan (Residivis). Dalam UU No 12 Tahun 1995 Pasal 2 Tentang Pemasyarakatan, menyebutkan bahwasanya didalam pemasyarakatan dalam membentuk Warga Binaan Pemasyarakatan atau Narapidana agar menjadi manusia yang seutuhnya, menyadari kesalahan, memperbaiki diri dan tidak mengulangi tindak pidana lagi sehingga dapat diterima kembali dalam lingkungan masyarakat, dan diharapkan juga dapat berperan aktif dalam pembangunan dan dapat hidup sewajarnya warga yang baik dan bertanggungjawab. Bukan bertujuan untuk melakukan pembalasan atas keadilan. Dalam penjatuhan sanksi pidana dalam hal tujuan memperbaiki si pelaku, mencakup 3 sasaran, yaitu :

a. Perbaikan yuridis agar si pelaku menaati UndangUndang

b. Perbaikan cara berpikir agar si pelaku insaf akan jeleknya kejahatan

c. Perbaikan moral agar si pelaku dari sisi nilai kesusilaan menjadi manusia yang bermoral baik

12 Soerjono Soekanto, Faktor-faktor yang mempengaruhi Penegakan Hukum, (Jakarta: Rajawali, 1986), hlm. 123.

13 I Dewa Gede Atmadja dan I Nyoman Putu Budiartha, Teori-Teori Hukum, (Malang : Setara Press, 2018), hlm. 175 
Namun dalam teori Pemidanaan ini terdapat juga kelemahan yang menonjol, antara lain: ${ }^{14}$

a. Dapat menimbulkan ketidakadilan, karena tidak membedakan kejahatan ringan dan berat yang keduaduanya disamakan

b. Kepuasan masyarakat diabaikan, karena hanya fokus memperbaiki sipelaku

c. Sulit dilaksanakan secara praktik karena bertujuan untuk mencegah dan menakut-nakuti tidak berlaku pada Narapidana Residivis.

Dilihat dari semua ini, tujuan pemidanaan bukan hanya mengarah kepada unsur pembalasan, akan tetapi dalam teori Pemidanaan ini juga mengarah pada tujuan memperbaiki karakter dari si pelaku atau terpidana.

\section{Kerangka Konseptual \\ Pembinaan}

Sistem pembinaan narapidana yang dikenal dengan nama Lembaga Pemasyarakatan, mulai dikenal sejak tahun 1946 dalam Konferensi Dinas Kepenjaraan di Lembaga tanggal 27 April 1946. Secara etimologi, pembinaan berarti pembaharuan, penyempurnaan, usaha, tindakan dan kegiatan yang dilakukan secara efisien dan efektif untuk memperoleh hasil yang lebih baik. Sedangkan secara terminologi pembinaan ialah kegiatan untuk meningkatkan kualitas keimanan kepada Tuhan yang Maha Esa, intelektual, sikap dan prilaku profesional serta kesehatan jasmani dan rohani narapidana. ${ }^{15}$ Sedangkan dalam pengertian menurut Mitha Thoha, pembinaan adalah suatu tindakan, proses, hasil atau pernyataan yang lebih baik. Dalam hal ini menunjukkan adanya kemajuan, peningkatan pertumbuhan, evolusi atas berbagai kemungkinan, berkembang atau peningkatan atas sesuatu. ${ }^{16}$

Sistem pemasyarakatan yang berdasarkan Pancasila dan Undang-Undang Dasar 1945 tidak sekedar mengandung aspek penjeraan, namun juga merupakan upaya untuk mewujudkan reintegrasi sosial warga binaan pemasyarakatan yaitu kembalinya kesatuan hubungan warga binaan pemasyarakatan baik sebagai pribadi, anggota masyarakat maupun insan Tuhan.

Dalam sistem pemasyarakatan Narapidana dipandang sebagai manusia yang memiliki fitrah kemanusiaan, i'tikad dan potensi yang dapat digali dan dikembangkan dalam rangka pembentukan manusia Indonesia seutuhnya. Prinsip-prinsip pembinaan dengan pendekatan tersebut tercermin dalam usaha-usaha pembinaan terhadap Narapidana berdasarkan sistem pemasyarakatan sebagaimana diatur dalam UndangUndang Nomor 12 Tahun 1995 pasal 5 yang berupaya mewujudkan reintegrasi sosial. Pasal ini memuat

14 I Dewa Gede Admadja dan I Nyoman Putu Budiartha, Ibid, 177

15 Peraturan Pemerintah Nomor 31 Tahun 1999 Tentang Pembinaan dan Pembimbingan Warga Binaan Pemasyarakatan

${ }^{16}$ Dwidja Priyatno, Ibid, hlm. 2 tentang prinsip pelaksanaan pemasyarakatan di Indinesia yang terdiri dari :

a. Pengayoman

b. Persamaan perlakuan dan pelayanan

c. Pendidikan

d. Pembimbingan

e. Penghormatan harkat dan martabat manusia

f. Kehilangan kemerdekaan merupakan satu-satunya penderitaan

g. Terjaminnya hak untuk tetap berhubungan dengan keluarga dan orang-orang tertentu. ${ }^{17}$

Sistem Lembaga Pemasyarakatan mengenal tahapan-tahapan sebagai pembinaan terhadap Narapidana. Proses pembinaan narapidana dilakukan dengean melalui empat tahapan, yaitu : ${ }^{18}$

a) Tahap Pertama, yang dilaksanakan sampai dengan $1 / 3$ masa pidananya

b) Tahap lanjutan, yang dilaksanakan antara $1 / 3$ sampai dengan $1 / 2$ masa pidananya

c) Tahap lanjutan, yang dilaksanakan antara $1 / 2$ sampai dengan $2 / 3$ masa pidananya

d) Tahap akhir, yang dilaksanakan antara $2 / 3$ masa pidananya sampai narapidana yang bersangkutan bebas.

Sistem pemasyarakatan memandang narapidana bukan sebagai objek melainkan sebagai subjek pembinaan yang pada hakikatnya melakukan perbuatan hukum karena adanya kerusakan hubungan hidup, kehidupan dan penghidupan.

\section{Narapidana}

Secara bahasa Narapidana adalah orang yang sedang menjalani hukuman karena telah melakukan suatu tindak pidana. Menurut Undang-Undang Nomor 12 Tahun 1995 tentang pemasyarakatan menjelaskan bahwa narapidana adalah terpidana yang sedang menjalani pidana hilang kemerdekaan di Lembaga Pemasyarakatan. ${ }^{19}$ Menurut pasal 1 ayat (6), UndangUndang No. 12 Tahun 1995, terpidana adalah seseorang yang terpidana berdasarkan putusan pengadilan yang telah memperoleh kekuatan hukum tetap.

Dari pernyataan diatas, dapat disimpulkan bahwa narapidana adalah orang atau terpidana yang sedang menjalani masa hukumannya di Lembaga Pemasyarakatan dimana kemerdekaan hilang. Dewasa ini narapidana tidak lagi dipandang sebagai objek melainkan menjadi subjek yang dihormati dan dihargai oleh sesamanya. Pada dasarnya yang harus diberantas

17 Undang-Undang Dasar RI Nomor 12 Tahun 1995 Tentang Pembinaan Pasal 5

18 Hamja, Pemberdayaan Lembaga Pemasyarakatan Terbuka Sebagi Wujud Pelaksanaan Community Based Corrections Didalam Sistem Peradilan Pidana di Indonesia, (Yogyakarta : CV Budi Utama, 2015), hlm. 11

${ }^{19}$ Undang-Undang RI Nomor 12 Tahun 1995 Tentang Pemasyarakatan Pasal 7 Ayat (1) 
ialah faktor penyebab tindak pidana, bukan pelaku tindak pidana.

\section{Wanita Hamil}

Menurut Poewodaminto pengertian wanita hamil adalah sebutan untuk orang perempuan yang telah mengandung, wanita yang telah bersuami, serta panggilan yang lazim pada wanita hamil. ${ }^{20}$ Wanita dalam pandangan islam pada masa jahiliyyah tidak berarti apa-apa, mereka hanya dijadikan sebagai bahan pemuas nafsu para lelaki, bahkan apabila mereka memiliki bayi perempuanpun dianggap aib sehingga jika lahir bayi perempuan ia akan di bunuh.

Kedudukan wanita dan laki-laki itu sama, apalagi bagi negara Indonesia yang berdasarkan pancasila. Jika laki-laki yang melakukan tindak pidana dihukum, maka wanita yang melakukan tindak pidanapun juga dihukum. Jika narapidana laki-laki mendapatkan pembinaan di Lembaga Pemasyarakatan, maka narapidana wanita harus mendapatkan pembinaan. Hanya saja ada sedikit perbedaan yaitu penangguhan hukuman bagi wanita jika sedang hamil atau menyusui. ${ }^{21}$

Tentang persamaan kedudukan antara wanita dan laki-laki ini telah dijelaskan didalam Al-Qur'an surah An-Nisa' ayat 124 :

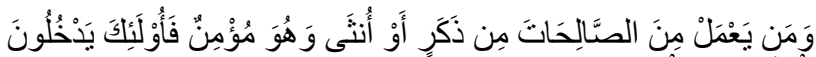

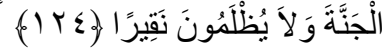

Artinya : “Barang siapa yang mengerjakan amal saleh, baik laki-laki maupun perempuan dalam keadaan beriman, maka sesungguhnya kami berikan kepadanya kehidupan yang baik". (QS An-Nisa' : $124)^{22}$

Ayat diatas menjelaskan adanya kesamaan kedudukan antara wanita dan laki-laki dihadapan Allah SWT, terkhusus dalam hal perolehan pahala dari amalamal shalehnya. Sebagaimana Rasulullah SAW bersabda:

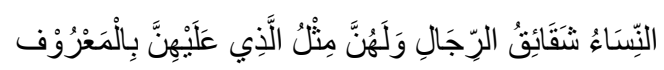

Artinya : "Sesungguhnya perempuan itu adalah saudara sekandung laki-laki, mereka para (wanita) mempunyai hak seimbang dengan kewajibannya menurut cara yang patut."(Riwayat Imam Abu Daud).

Maka, pada dasarnya apapun yang ditetapkan sebagai hukum bagi kaum laki-laki, juga berlaku sepenuhnya bagi kaum wanita. Kecuali, jika ada keterangan dari nash syariat yang menerangkan

20 Suprayanto, Definisi Ibu Hamil. DrSuprayanto.blogspot.com, diakses Pada Hari Rabu, 29 Januari 2020, Pukul 14.20 WIB

${ }^{21}$ Fita Lisani, Ibid, hlm.12

${ }^{22}$ Al-Qur'an Surah An-Nisa' ayat 124 mengenai kekhususannya, maka teks-teks nash tersebutlah yang menjadi pengecualian dari hadist diatas.

\section{Lembaga Pemasyarakatan Perempuan (LPP)}

Lembaga Pemasyarakatan atau disingkat denfgan LAPAS ataupun penjara merupakan tempat melakukan pembinaan terhadap narapidana. Dulu sebelum adanya Lembaga Pemasyarakatan tempat tersebut dikenal dengan istilah penjara. R.A. Koesnan berpendapat, berdasarkan etimologi kata penjara berasal dari bahasa jawa (penjoro) yang artinya tobat atau jera dipenjara. Lembaga ialah ikatan, badan atau organisasi yang tugasnya melakukan suatu penyelidikan atau suatu usaha. Sedangkan Pemasyarakatan ialah kegiatan untuk melakukan pembinaan warga binaan pemasyarakatan berdasarkan sistem, kelembagaan dan cara pembinaan yang merupakan bagian akhir dari sistem peradilan pidana. Sistem peradilan pidana sendiri terdiri dari empat (4) sub-sistem, yaitu : Kepolisian, Kejaksaan, Pengadilan dan Lembaga Pemasyarakatan. Jadi, dapat disimpulkan bahwa Lembaga Pemasyarakatan ialah tempat untuk melaksanakan pembinaan yang mana penghuni didalamnya bisa Narapidana atau Warga Binaan Pemasyarakatan (WBP) dan bisa juga yang statusnya masih tahanan, maksudnya yang setatusnya masih berada dalam proses peradilan dan belum ditentukan bersalah atau tidaknya oleh hakim. ${ }^{23}$

Lembaga Pemasyarakatan sebagai lembaga koreksi merupkan faktor penentu dari keberhasilan sistem peradilan pidana. Di Lembaga Pemasyarakatan proses pemidanaan menjadi tempat "Pengolahan" sampai pada kriteria tertentu ketika sudah kembali dalam masyarakat. Jadi, pembinaan dikhususkan pada pembinaan Narapidana sekaligus pengayoman terhadap masyarakat. ${ }^{24}$

Didalam pembinaan Narapidana wanita diberikan tempat pembinaan khusus yang diberi nama Lembaga Pemasyarakatan Perempuan atau disingkat dengan LPP. Lembaga Pemasyarakatan khusus Perempuan berdiri karena intervensi terhadap narapidana wanita harus berbeda dengan narapidana laki-laki maupun anak-anak. Seharusnya terdapat pembeda dalam bentuk LAPAS serta kegiatan-kegiatan yang dilakukan karena banyaknya kesetresan yang sering dialami oleh Narapidana wanita namun tidak dialami Narapidana laki-laki. Seperti banyaknya berpikir tentang keluarga terutama anak yang harus ditinggalkan. ${ }^{25}$

\section{Tinjauan Pustaka}

Tinjauan pustaka sangat diperlukan dalam proses pembuatan skripsi untuk menambah wawasan tentang

${ }^{23}$ Undang-Undang RI Nomor 12 Tahun 1995 Tentang Pemasyarakatan, Pasal 1 angka 3

${ }^{24}$ Hamja, Ibid, hlm. 13

${ }^{25}$ Puti Halimah, Dessy Hasanah,Hery Wibowo, Jurnal, Pola Pembinaan Narapidana Wanita Oleh Lembaga Pemasyarakatan Dalam Prespektif Pekerjaan Sosial, hlm. 322 
masalah yang akan dikaji. Tinjauan pustaka dijadikan sebagi perbandingan terhadap penelitian yang dilakukan sebelumnya yang memiliki kesamaan. Adapun penelitian mengenai pembinaan terhadap narapidana wanita hamil telah banyak dibahas oleh banyak peneliti, baik yang dituangkan berupa buku, skripsi, jurnal serta artikel. Dari beberapa penelitian yang sudah penulis telusuri antara lain:

1. Skripsi yang disusun oleh Fita Lisani dengan judul "pembinaan terhadap narapidana wanita di lembaga pemasyarakatan anak dan wanita muara bulian menurut hukum pidana islam". ${ }^{26}$ Dari penelitian ini peneliti membahas tentang seberapa jauh perkembangan pembinaan narapidana wanita di Lembaga Pemasyarakatan. Pada penelitian ini terdapat persamaan dan perbedaan dari penelitian yang akan diteliti. Persamaannya yaitu sama-sama meneliti tentang pembinaan terhadap narapidana wanita, sedangkan perbedannya pada skripsi karya Fita Lisani yang diteliti ialah hanya pada perkembangan terhadap pembinaan narapidana wanita biasa, namun pada penelitan yang akan diteliti ini yaitu tentang pembinaan terhadap narapidana wanita yang hamil.

2. Skripsi yang disusun oleh Tirsa D.G Ticoalu yang berjudul "Perlindungan Hukum pada Narapidana Wanita Hamil di Lembag Pemasyarakatan”. Dari penelitian yang dilakukan oleh Tirsa D.G Ticoalu ia meneliti tentang perlindungan hukum bagi seorang narapidana wanita hamil serta sistem pembinaan dan hak yang dimiliki pada saat berada dalam Lembaga Pemasyarakatan. ${ }^{27}$ Penelitian ini memiliki persamaan dan perbedaan dengan penelitian yang akan diteliti tentang pembinaan terhadap narapidana wanita hamil di Lembaga Pemasyarakatan kelas II B Jambi. Persamaan pada penelitian ini yaitu sama-sama meneliti tentang narapidana wanita yang hamil. Perbedaannya, pada skripsi karya Tirsa D.G Ticoalu meneliti tentang Perlindungan Hukum pada Narapidana wanita hamil sedangkan pada penelitian yang akan diteliti yaitu tentang Pembinaan terhadap Narapidana wanita hamil.

3. Jurnal karangan Lily Lastriana Dewi dengan judul “ Pembinaan Narapidana Wanita yang Mempunyai Anak Balita dan dalam Keadaan Mengandung di Lembaga Pemasyarakatan Wirogunan Yogyakarta". ${ }^{28}$ Dalam penelitian ini penulis meneliti tentang bagaimana sistem pembinaan Narapidana wanita yang mempunyai anak balita atau dalam keadaan mengandung serta faktor yang menghambat pelaksanaannya. Dalam penelitian ini hampir sama

${ }^{26}$ Fita Lisani, Ibid, hlm. 14

${ }^{27}$ Tirsa D.G Ticoalu, Skripsi, Perlindungan Hukum Pada Narapidana Wanita Hamil di Lembaga Pemasyarakatan, Mahasiswa Fakultas Hukum Universitas Sam Ratulangi, 2013, hlm. 125

${ }^{28}$ Lily Lastriana Dewi, Ibid, hlm. 2 dengan penelitian yang penulis akan teliti, hanya terdapat sedikit perbedaan dari penelitian tentang Pembinaan Terhadap Narapidana Wanita Hamil di Lembaga Pemasyarakatan kelas II B Jambi. Perbedaannya, pada penelitian yang dilakukan oleh Lily Lastriana Dewi terdapat penelitian tentang Sistem Pembinaan Narapidana Wanita yang mempunyai Anak Balita sedangkan dalam penelitian yang akan diteliti hanya akan mengambil penelitian tentang Pembinaan Trhadap Narapidana wanita hamil. Persamaannya yaitu sama-sama terdapat penelitian tentang sistem Pembinaan Terhadap Narapidana Wanita yang dalam keadaan Mengandung atau Hamil.

\section{METODE \\ Jenis Penelitian}

Pendekatan yang digunakan dalam penelitian ini adalah pendekatan yuridis empiris. Pendekatan yuridis empiris dalam penelitian ini maksudnya adalah bahwa dalam menganalisis permasalahan dilakukan dengan cara memadukan bahan-bahan hukum (yang merupakan data sekunder) dengan data primer yang diperoleh di lapangan yaitu tentang pembinaan narapidana wanita yang hamil di lembaga permasyarakatan Perempuan kelas II B Jambi. Sesuai dengan tema, maka penelitian ini menggunakan metode kualitatif deskriptif. Menurut Sugiono bahwa penelitian kualitatif deskriptif adalah metode penelitian yang berlandaskan pada filsafat postpositivisme yang biasanya digunakan untuk meneliti pada kondisi objektif yang alamiah dimana peneliti berperan sebagai instrumen kunci. ${ }^{29}$

\section{Lokasi atau Daerah Penelitian}

Penelitian ini dilakukan di Sengeti Kabupaten Muaro Jambi, dan obyek dari penelitian ini adalah Lembaga Permasyarakatan Perempuan Kelas II B Jambi.

\section{Jenis dan Sumber Data \\ Data Primer}

Data primer adalah data pokok yang diperlukan dalam penelitian yang diperoleh secara langsung dari sumbernya ataupun dari lokasi obyek penelitian atau keseluruhan data hasil penelitian yang diperoleh dilapangan. Dalam penelitian ini, data primer dapat diperoleh secara langsung melalui penelitian lapangan di Lembaga Permasyarakatan Perempuan kelas II B Jambi.

\section{Data Skunder}

Data skunder adalah data yang diperoleh dari bahan perpustakaan atau literatur yang mempunyai hubungan dengan objek penelitian. ${ }^{30}$ Data ini diperoleh dengan cara mengutip dari sumber lain, sehingga tidak

\footnotetext{
${ }^{29}$ Sugiono, Ibid, hlm. 16

30 Ishaq, Metode Penelitian Hukum dan Penulisan
} Skripsi, Tesis, Serta Disertasi, Cetakan ke 1, (Bandung : Alfabeta), hlm. 100 
bersifat autentik, karena sudah diperoleh dari tangan kedua, ketiga dan seterusnya. Adapun yang menjadi data skunder dalam penelitiaan ini yaitu berupa buku, skripsi, jurnal, serta tulisan-tulisan penting lainnya yang menyangkut tentang Narapidana Wanita yang Hamil.

\section{Sumber Data}

Sumber data dalam penelitian adalah subyek dari mana data tersebut dapat diperoleh. Dalam penelitian ini, sumber data dapat diperoleh dari penelitian lapangan yang berupa hasil dari suatu wawancara serta dokumentasi yang dilakukan di lapangan.

\section{Teknik Pengumpulan Data Observasi}

Metode observai adalah proses untuk memperoleh penelitian dengan cara pengamatan dan pencatatan terhadap fenomena-fenomena yang terjadi di lapangan. Pada penelitian ini, penulis tidak dapt mengamati secara langsung pristiwa-pristiwa yang terjadi dikarenakan adanya Covid-19. Penulis hanya mendapat gambaran mengenai Pembinaan Narapidan wanita yang hamil oleh petugas yang ada di Lembaga Permasyarakatan Perempuan kelas II B Jambi.

\section{Wawancara}

Wawancara adalah tanya jawab antara dua pihak yang dilakukan antara pewawancara dengan narasumber untuk memperoleh data, keterangan atau pendapat tentang suatu hal. Dilakukan secara lisan baik langsung (face to face) maupun tidak langsung (menggunakan telepon) atas dasar tujuan yang ingin dicapai. Dari penelitian ini, penulis melakukan wawancara dengan metode tanya jawab secara langsung (face to face) dan tidak langsung (menggunakan telepon). ${ }^{31}$

\section{Dokumentasi}

Dokumentasi merupakan sumber data yang digunakan untuk melengkapi penelitian, selain dengan metode observasi dan wawancara, data penelitian juga dapat dikumpulkan dengan metode ini, yang bersumber dari buku-buku yang terkait, dokumen-dokumen yang relavan dengan penelitian, catatan-catatan, foto-foto serta laporan-laporan lain yang semua itu memberikan informasi terhadap proses penelitian dan sebagai pelengkap bagi metode observasi dan wawancara.

\section{Teknik Analisis Data}

Pengumpulan data dan analisis data adalah suatu kegiatan yang tidak dapat dipisahkan. Menurut Patton Analisis data adalah mengatur urutan data, mengorganisasikannya ke dalam suatu pola, kategori dan satuan uraian dasar. ${ }^{32}$ Analisis data itu dilakukan dalam

\footnotetext{
${ }^{31}$ Sugiyono, Ibid. hlm. 16

${ }^{32}$ Lexy J. Moleong, Metodologi Penelitian Kualitatif,
} Cetakan ke 25, ( Bandung: PT. Remaja Rosdakarya, 2008), hlm. 280 suatu proses mencari dan menyusun secara sistematis data yang diperoleh dari hasil wawancara, observasi dan dokumentasi yang dilakukan pada saat pengumpulan data berlangsung dan setelah data yang diperoleh dari lapangan dalam waktu tertentu, dan membuat kesimpulan sehingga mudah difahami oleh diri sendiri dan orang lain. Untuk menganalisis data yang diperoleh dari lapangan, maka penulis menganalisis data dengan menggunakan langkah-langkah sebagai berikut :

\section{Reduksi Data}

Data yang diperoleh dari lapangan tentu jumlahnya banyak serta campur aduk, maka dari itu perlu bagi peneliti untuk mereduksi data. Reduksi data adalah merangkum peneliti dalam memilih dan memilah data pokok yang dianggap relavan, memfokuskan pada hal-hal yang penting, mencari pola yang sesuai dengan tema skripsi yang kemudian akan disajikan. ${ }^{33}$ Dengan demikian data yang telah direduksi akan memberikan gambaran yang lebih jelas dan mempermudah peneliti untuk melakukan pengumpulan data selanjutnya. Kegiatan ini berlangsung sejak awal hingga akhir penelitian.

\section{Penyajian Data (Display Data)}

Setelah data direduksi, maka selanjutnya adalah penyajian data. Bentuk penyajian data adalah dengan teks yang bersifat naratif sehingga memudahkan untuk memahami apa sebenarnya yang terjadi dan selanjutnya melaksanakan kerja berdasarkan apa yang telah difahami.

Dalam prakteknya tidak semudah ilustrasi yang diberikan, karena fenomena sosial bersifat kompleks dan dinamis, sehingga apa yang ditemukan pada saat memasuki lapangan dan setelah berlangsung agak lama di lapangan akan mengalami perkembangan data. Untuk itu maka peneliti harus selalu menguji apa yang telah ditemukan pada saat memasuki lapangan, apakah data yang akan diteliti itu berkembang atau tidak.

\section{Penarikan Kesimpulan (Verifikasi Data)}

Penarikan kesimpulan merupakan bagian akhir dari sebuah penelitian yang disusun sesuai dengan tujuan penelitian. Maka harus segera dicatat penelitian dari hasil wawancara agar tidak hilang dan lupa. Karena wawancara yang dilakukan tidak terstruktur maka peneliti perlu membuat rangkuman yang lebih sistematis terhadap hasil wawancara, observasi dan dokumentasi. Dari berbagai sumber data, perlu dicatat mana data yang dianggap penting dan data yang tidak penting.

\section{HASIL DAN PEMBAHASAN}

Pembinaan Terhadap Narapidana Wanita Hamil di Lembaga Pemasyarakatan Perempuan Kelas II B Jambi 


\section{Pembinaan Kepribadian}

Program Pembinaan Kepribadian ini bertujuan untuk menumbuhkan kepercayaan dan kemampuan diri Narapidana, meningkatkan kualitas agar memiliki mental spiritual (agama) yang baik, taat menjalankan perintah agama, memiliki kesadaran hukum yang baik, dan memiliki kemampuan intelektual yang baik sehingga bisa kembali diterima oleh masyarakat setelah habis masa hukumannya. Pembinaan Kepribadian di LPP Kelas II B Jambi terdiri dari ceramah agama, pengajian Al-Qur'an, belajar pendidikan umum dan pengalaman pancasila.

\section{Pembinaan Kemandirian}

Diterapkannya pembinaan kemandirian dengan tujuan agar terpidana mempunyai keahlian atau kecakapan teknis yang berguna bagi dirinya dan dapat dijadikan bekal ketika telah keluar dari LPP Kelas II B Jambi. Secara umum program ini bertujuan untuk membentuk kemandirian manusia. ${ }^{34}$ Pembinaan Kemandirian diarahkan pada pembinaan bakat dan keterampilan agar Narapidana dapat kembali berperan sebagai anggota masyarakat yang bebas dan bertanggung jawab. Pembinaan kemandirian ini meliputi pelatihan salon, pelatihan membatik, pelatihan tata boga, pelatihan bercocok tanam dan lain sebagainya yang telah diprogramkan di LPP Kelas II B Jambi.

Untuk Narapidana wanita yang hamil diperintahkan untuk tetap melaksanakan kewajibanya yang telah diprogramkan dalam pembinaan Narapidana, sebagaimana yang telah ditetapkan oleh pihak LPP, namun dalam melaksanakannya tidak seperti Narapidana wanita pada umumnya. Berdasarkan hasil wawancara bersama bapak Muryono selaku bidang Registrasi dan Binkemas, bahwa:

"pembinaan terhadap Narapidana Wanita Hamil di LPP Kelas II B Jambi tetap disamakan dengan pembinaan terhadap Narapidana lain pada umumnya, pihak LPP tidak membedakan, namun memang ada kebutuhan yang harus di berikan untuk Narapidana wanita hamil". ${ }^{35}$

Berdasarkan pada teori Pemidanaan, hukuman yang diberikan kepada Narapidana pada saat ini bertujuan untuk memperbaiki diri akibat kejahatan yang pernah dilakukan, ${ }^{36}$ sehingga jika Narapidana sudah keluar dari LAPAS maka dia dapat diterima kembali di masyarakat. Seperti halnya Narapidana yang pada saat ini telah hamil namun mereka tidak bisa bebas layaknya wanita-wanita hamil diluar sana akibat suatu kesalahan yang mereka perbuat. Akan tetapi, pembinaan dari pihak

${ }^{34}$ Hamja, Ibid, hlm. 175

35 Hasil wawancara bersama bapak Muryono selaku bidang Registrasi dan Bemkemas, tanggal 30 November 2020

36 I Dewa Gede Atmadja, I Nyoman Putu Budiartha, Teori-Teori Hukum, (Malang : Setara Press, 2018), hlm. 12
LPP tetap memberikan hak-hak atas Narapidana yang hamil serta tetap memberikan kewajiban yang harus dipatuhi.

Adapun kewajiban-kewajiban yang ditetapkan oleh pihak LPP sesuai dengan yang tercantum dalam Peraturan Mentri Hukum dan Hak Asasi Manusia RI Nomor 6 Tahun 2013 Tentang Tata Tertib Lembaga Pemasyarakatan dan Rumah Tahanan Pasal 3 yang berbunyi, "Setiap Narapidana atau Tahanan wajib :37

1. Taat menjalankan ibadah sesuai agama dan/atau kepercayaan yang dianutnya serta memelihara kerukunan beragama

2. Mengikuti seluruh kegiatan yang di programkan

3. Patuh, taat dan hormat kepada petugas

4. Mengenakan pakaian seragam yang telah ditentukan

5. Memelihara kerapian diri dan lingkungan hunian serta mengikuti kegiatan yang dilaksanakan dalam rangka kebersihan lingkungan hunian, dan

6. Mengikuti apel kamar yang dilaksanakan oleh petugas pemasyarakatan.

Namun dari kewajiban-kewajiban tersebut, pihak LPP telah memberikan keringanan atau toleransi kepada Narapidana wanita yang hamil untuk tidak melakukan semua kewajiban tersebut, seperti kegiatan rutinitas setiap pagi yaitu apel kamar, olahraga yang rutinitas dilakukan oleh seluruh Narapidana pada setiap pagi sabtu, gotong royong dan kegiatan lain yang diprogramkan yang membahayakan kandungan. Itu tidak wajib bagi Narapidana wanita hamil untuk dilakukan. Akan tetapi kewajiban dari segi keagamaan yang termasuk dalam pembinaan kepribadian tetap wajib dilakukan oleh seluruh Narapidana, termasuk Narapidana yang hamil.

Kewajiban lain yang dimiliki Narapidana sesuai dengan Peraturan Mentri Hukum dan Hak Asasi Manusia RI Nomor 6 Tahun 2013 Tentang Tata Tertib Lembaga Pemasyarakatan dan Rumah Tahanan Pasal 3 huruf (b) yaitu, Narapidana wajib melaksanakan kegiatan yang diprogram oleh LPP.$^{38}$ Seperti yang sudah dijelaskan oleh Bapak Muryono selaku bidang Registrasi dan Binkemas bahwa di LPP Kelas II B Jambi dalam pembinaan kemandirian menyediakan berbagai program kegiatan yang dapat dipekerjakan oleh Narapidana didalamnya. Adapun kegiatan-kegiatan yang terdapat di LPP Kelas II B Jambi, sebagai berikut : ${ }^{39}$

1. Membatik

2. Menjahit

3. Salon

4. Tata boga

${ }^{37}$ Peraturan Pemerintah No 6 Tahun 2013, Tata Tertib Lembaga Pemasyarakatan dan Rumah Tahanan Pasal 3

38 Peraturan Pemerintah No 6 Tahun 2013, Tentang Tata Tertib Lembaga Pemasyarakatan dan Rumah Tahanan Pasal 3

39 Hasil wawancara bersama bapak Muryono selaku bidang Registrasi dan Bemkemas, tanggal 30 November 2020 
5. Peternakan

6. Pertanian

7. Perikanan

8. Sablon

9. Kerupuk nasi

10.Nasi kering

11.Sampah

12.Biopori, membuat lubang sampah jadi pupuk

Dari berbagai macam kegiatan diatas Narapidana tersebut hanya dapat dipekerjakan sesuai dengan bakat kemampuannya. Untuk Narapidana wanita hamil yang kandungannya masih dalam usia 1-5 bulan, dari pihak LPP masih diperbolehkan untuk mengikuti kegiatan tersebut. Namun jika kandungan sudah memasuki usia 7 bulan keatas maka Narapidana wanita yang hamil tidak diwajibkan untuk melakukan pekerjaan tersebut, karena dikhawatirkan terhadap kondisi kandungan.

Begitu pula dengan hak-hak Narapidana wanita yang hamil di LPP Kelas II B Jambi, pembinaan mereka tetap disamakan dengan Narapidana pada umumnya. Sebagaimana pelaksanaan hak narapidana wanita yang terdapat dalam peraturan pemerintah Nomor 32 Tahun 1999 tentang Syarat dan Tata Cara Pelaksanaan Hak Warga Binaan Pemasyarakatan. Dimana dalam pasal 20 mengatur perlindungan terhadap narapidana wanita, yaitu : 40

1. Narapidana dan anak didik pemasyarakatan yang sakit, hamil dan menyusui berhak mendapat makanan tambahan sesuai dengan petunjuk dokter.

2. Makanan tambahan juga diberikan kepada narapidana yang melakukan pekerjaan jenis tertentu.

3. Anak dari narapidana wanita dibawa kedalam Lembaga Pemasyarakatan ataupun yang lahir di Lembaga Pemasyarakatan dapat diberi makanan tambahan atas petunjuk dokter, paling lama sampai berumur 2 tahun.

4. Dalam hal anak sebagaimana dimaksud dalam ayat 3 telah mencapai umur 2 tahun, harus diserahkan kepada sanak keluarganya.

5. Untuk kepentingan kesehatan anak, kepala Lembaga Pemasyarakatan dapat menentukan makanan tambahan.

Hak-hak diatas yang tertuang dalam peraturan pemerintah Nomor 32 Tahun 1999 tentang Syarat dan Tata Cara Pelaksanaan Hak Warga Binaan Pemasyarakatan menjelaskan bahwa bagi Narapidana yang sakit, hamil, menyusui, Narapidana yang mendapatkan pekerjaan tertentu serta anak dari Narapidana yang melahirkan mereka berhak mendapat makanan tambahan. Batas anak Narapidana mendapatkan makanan tambahan sampai anak tersebut

40 Peraturan Pemerintah No. 32 Tahun 1999 Tentang Syarat dn Tata Cara Pelaksanan Hak Warga Binaan Pemasyarakatan Pasal 20 berusia 2 tahun. Dan ketika anak sudah mencapai usia 2 tahun maka wajib diserahkan pada pihak keluarga.

Hak lain yang dimiliki oleh seorang Narapidana terdapat dalam Peraturan Pemerintah No 32 Tahun 1999 Pasal 5 Tentang syarat-syarat dan Tata Cara Pelaksanaan Hak Warga Binaan Pemasyarakatan, yang mengatur tentang hak yang dimiliki oleh setiap Narapidana dan anak didik pemasyarakatan untuk mendapat perawatan jasmani dan rohani. Dan pasal 14 ayat (1), setiap Narapidana dan anak didik pemasyarakatan berhak mendapatakan pelayanan kesehatan yang bagus.

Berdasarkan hasil wawancara bersama Bapak Muryono selaku bidang Registrasi dan Binkemas, bahwa:

"Petugas LPP telah memberikan hak didalam pembinaan terhadap Narapidana wanita hamil guna untuk memenuhi kebutuhanya, meskipun hak tersebut masih terbatas". ${ }^{41}$

Pihak LPP Kelas II B Jambi belum memeberikan hak secara khusus kepada Narapidana wanita hamil seperti yang dijelaskan dalam Peraturan Pemerintah diatas, akan tetapi dari pihak LPP tetap memberikan hak yang dibutuhkan oleh Narapidana wanita hamil, meskipun masih banyak hak-hak lain yang belum terealisasikan, seperti:

1. Mendapatkan makanan tambahan jika membutuhkan

Sesuai dalam Peraturan Pemerintah No 32 Tahun 1999 Tentang syarat-syarat dan Tata Cara Pelaksanaan Hak Warga Binaan Pemasyarakatan dalam pasal 20 ayat (1). Bahwa Narapidana yang hamil berhak mendapatkan makanan tambahan sesuai dengan petunjuk dokter. Sebagaimana hasil wawancara dengan Bapak Ady Setiono, A.Md.kep selaku bidang kesehatan, bahwa menu makanan harian yang diberikan oleh seluruh Narapidana termasuk Narapidana wanita hamil sudah sesuai dengan kalori kesehatan dan telah memenuhi gizi yang cukup, sehingga dari pihak LPP tidak menyediakan makanan tambahan untuk Narapidana wanita hamil. $^{42}$

Berdasarkan dari hasil pengamatan penulis pada hari Senin tanggal 30 September 2020, untuk menu makan Narapidana di LPP baik Narapidana pada umumnya atau Narapidana hamil adalah nasi putih, dengan lauk tahu goreng, ikan atau ayam goreng dan sayur kangkung. Pemberian makanan tambahan akan diberikan kepada Narapidana wanita hamil apabila dirasa butuh, seperti kondisi yang kurang baik, serta sistem kekebalan tubuh yang menurun.

${ }^{41}$ Wawancara bersama Bapak Muryono, selaku bidang Registrasi dan Bimkemas, Tanggal 30 Novem ber 2020

${ }^{42}$ Wawancara bersama Bapak Ady Setiono, A.Md.kep, selaku bidang kesehatan, pada tanggal 30 November 2020 


\section{Mendapatkan pelayanan kesehatan}

Bidang kesehatan di LPP selalu menjaga kesehatan apalagi mengenai kadungann. Meskipun fasilitas kesehatan didalam LPP masih belum lengkap dan belum adanya dokter dari LPP sendiri, akan tetapi pihak LPP tetap rutin melakukan pemeriksaan kandungan terhadap Narapidana yang hamil dalam setiap bulannya dengan tujuan untuk mengetahui kondisi kandungan. bahkan sebelum datangnya Covid-19 pihak LPP selalu mendatangkan pihak kesehatan ke LPP 2 kali dalam sebulan berlaku untuk seluruh Narapidana yang dalam keadaan tidak sehat, dengan tujuan agar Narapidana di LPP Kelas II B Jambi selalu dalam keadaan sehat .

Berdasarkan Undang-Undang Pemasyarakatan dalam pasal 14 ayat 1 huruf (b) tentang mendapatkan perawatan jasmani dan rohani sekaligus mendapatkan fasilitas yang layak yaitu tempat khusus (kamar) yang diberikan kepada Narapidana wanita hamil sekaligus anaknya. ${ }^{43}$ Ibu Kurniati, S.H.I selaku bidang Tata Usaha mengatakan bahwa memang seharusnya Narapidana yang hamil atau anak diberikan tempat yang khusus (kamar). Namun pada saat ini di LPP Kelas II B Jambi belum menyediakan kamar khusus Narapidana wanita hamil, sehingga masih bergabung dengan Narapidana lainnya. ${ }^{44}$

Mengenai vitamin tambahan, tidak diberikan secara khusus dari pihak LPP, akan tetapi Narapidana yang hamil mendapatkan vitamin berupa obat-obatan tersebut dari pihak dokter ketika mereka melakukan pemeriksaan kandungan. Kebutuhan lain berupa susu hamil juga ditanggung sendiri oleh Narapidana yang hamil.

Pelaksanaan hak-hak lain narapidana wanita yang hamil berdasarkan kebijakan yang dibuat oleh LPP Kelas II B Jambi, seperti :

1. Memberikan dispensasi untuk tidak mengikuti kegiatan olahraga

2. Memberikan dispensasi untuk tidak mengikuti kegiatan kerja bakti

3. Memberikan dispensasi terhadap kegiatan-kegiatan yang membahayakan kesehatan si ibu maupun kandungan.

Jumlah Narapidana wanita yang hamil setelah LAPAS Perempuan resmi berdiri sendiri di tahun 2019 sampai tahun 2020 saat ini, terdapat 7 Narapidana wanita hamil. ${ }^{45}$ Ditahun 2019 berjumlah 2 (Dua) orang, keduaduanya dengan kasus Kriminal. Satu kasus Kriminal

${ }^{43}$ Undang-Undang RI Nomor 12 Tahun 1995 Tentang Pemasyarakatan Pasal 14 Ayat 1 huruf (b)

${ }^{44}$ Berdasarkan hasil wawancara bersama Ibu Kurniati, S.H.I selaku bidang Tata Usaha, pada tanggal 30 November 2020

45 Hasil Wawancara bersama Ibu Yosi selaku bidang Binadik dan Giatja, pada hari Senin, 28 Desember 2020 dalam bentuk Penggelapan Mobil. dan satu kasus Kriminal dalam bentuk Penipuan jual beli mobil travel. Sedangkan di tahun 2020 terdapat 5 (Lima) orang Narapidana wanita yang hamil. Tiga dengan kasus Kriminal dan Dua dengan kasus Narkotika. Kriminal dalam bentuk Penganiayaan berupa Pengancaman, Kriminal dalam bentuk Penganiayaan terhadap suami yang melakukan perselingkuhan, Kriminal dalam bentuk Penggelapan berupa Penawaran Bisnis dan terakhir dengan kasus Narkotika jenis Shabu. Dari keseluruhan Napi yang hamil tersebut sekarang sudah melahirkan semua dan terakhir melahirkan tanggal 20 November 2020.

Tabel 1. Jumlah NAPI Wanita Hamil Tahun 2019-2020

\begin{tabular}{clcc}
\hline No & Nama Narapidana & Kasus & Tahun \\
\hline 1 & Marlinda Binti Bakri & Kriminal & 2019 \\
2 & Dia Eka Sari, S.Pd Binti Ismail & Kriminal & \\
3 & Deli Fitri Eka Sari Binti Mucklis & Kriminal & \\
4 & Ria Asnita Binti Ismail & Kriminal & 2020 \\
5 & Noveria Muharlinda Binti Padri & Kriminal & \\
6 & Septia Suci Adila Binti Suhatril & Narkotika & \\
7 & Tera Darmawati & Narkotika & \\
\hline
\end{tabular}

Sumber : Kasi Binadik dan Giatja LPP Kelas II B Jambi

Dari keseluruhan Narapidana wanita yang hamil di atas, mereka hamil sebelum resmi berstatus menjadi seorang Narapidana, dan masuk kedalam Lapas dalam keadaan hamil dengan usia kandungan yang berbeda. Saudari Marlinda masuk ke LPP dengan usia kandungan 8 bulan, Dia Eka Sari dengan usia 3 bulan, Deli usia 8 bulan, Ria usia 3 bulan, Noveria usia 3 masuk 4 bulan, Septia usia 9 bulan dan Teri dengan usia kandugan 5 bulan.

Untuk tempat khusus layanan kunjungan bagi para suami dari Narapidana wanita di LPP Kelas II B Jambi memang tidak disediakan, bukan hanya di LPP Kelas II B Jambi, Bapak Muryono mengatakan diseluruh LAPAS yang ada di Indonesia pada saat ini tidak menyediakan tempat layanan khusus bagi para suami dari Narapidana wanita. ${ }^{46}$ Karena takut terjadi hal-hal yang tidak diinginkan ketika disediakannya tempat khusus bagi suami dari Narapidana wanita. Seperti adanya pengunjung yang datang dengan mengakui bahwa dirinya adalah suami dari salah satu Narapidana wanita, padahal pada kenyataannya mereka bukan pasangan suami istri. Seperti yang dikatakn oleh Bapak Muryono bahwa untuk bukti surat nikah saja pada saat ini belum meyakinkan.

Berdasarkan hasil wawancara bersama Ibu Kurniati, S.H.I selaku bidang Tata Usaha Di LPP Kelas II B Jambi, bahwa pada umumnya dari pihak LPP mengedepankan untuk masalah kesehatan, seperti kejadian Narapidana yang melahirkan pada bulan November 2020 pihak LPP melakukan tindakan yang

46 Hasil wawancara Bapak Muryono selaku bidang Registrasi dan Bimkemas, pada hari senin, 30 November 2020 
cepat. ${ }^{47}$ Ketika dari Narapidana wanita yang hamil sudah diketahui beberapa tanda-tanda seperti air ketuban yang sudah pecah, atau tanda lainnya, maka pihak LPP akan bertanggungjawab atas proses lahiran dan segera membawa Narapidana ke Rumah Sakit terdekat dan menginformasikan langsung kepada pihak keluarganya, karena di LPP belum disediakan fasilitasnya dan dokter pribadi dari LPP juga tidak disediakan.

Pihak LPP Kelas II B Jambi telah melakukan kerja sama dengan beberapa Rumah Sakit diluar, seperti Rumah Sakit Arifin Ahmad, Raden Mataher dan Rumah Sakit Bhayangkara. Pada proses persalinan, dari pihak LPP tetap menugaskan beberapa pegawai untuk menjaga Narapidana di Rumah Sakit sampai Narapidana kembali ke LPP, Ibu Nia selaku bidang Tata Usaha mengatakan, untuk pegawai yang ditugaskan biasanya diperintahkan dua orang untuk berjaga di Rumah Sakit. Mengenai biaya persalinan dari Narapidana ditanggung oleh pihak keluarga, karena dari pihak LPP memang tidak menyediakan anggaran dari biaya persalinan para Narapidana. Akan tetapi, jika dari pihak keluarga tidak mampu untuk menangani pembiayaan dari persalinan tersebut maka akan dibantu oleh pihak sosial.

Setelah proses persalinan selesai, untuk masalah anak akan diserahkan kepada pihak keluarga, apakah anak akan dibawa ke pihak Lapas bersama Ibunya atau dibawa langsung bersama pihak keluarga. Sebagaimana hasil wawancara pada hari Senin, 30 November 2020 bersama salah satu Narapidana yang sempat merasakan hamil sampai dengan proses melahirkan berada dalam Lapas, yaitu dengan Ibu Noveria dengan kasus Kriminal. Beliyau masuk kedalam LPP pada tanggal 12 Maret 2020 dengan usia kehamilan 3 bulan masuk ke 4 bulan. Beliyau mengatakan bahwa:

"Pembinaan yang diberikan oleh pihak LPP Kelas II B Jambi terhadap Narapidana wanita yang hamil tetap disamakan dengan pembinaan yang diberikan terhadap Narapidana pada umumnya, akan tetapi diberi keringanan untuk tidak melakukan pekerjaan yang berat-berat yang membahayakan kandungan, Ibu serta janin. Pihak LPP sangat memperhatikan mengenai kesehatan, mereka memberikan pelayanan kesehatan dengan menggunakan fasilitas yang ada." ${ }^{48}$

Pembinaan yang diberikan tetap sama, hak yang diberikan pun terbatas tidak semua hak untuk Narapidana hamil harus diberikan karena terhalang oleh dana serta fasilitas. Beliyau melakukan persalinan pada bulan Agustus 2020, dan menyerahkan anaknya langsung kepada pihak keluarga, dengan alasan jika dibawa ke pihak LPP untuk pada saat ini ditakutkan terjadinya hal-hal yang tidak diinginkan karena masih

\footnotetext{
${ }^{47}$ Hasil wawancara bersama Ibu Kurniati, S.H.I selaku bidang Tata Usaha, pada tanggal 30 November 2020

48 Wawancara bersama Ibu Novaria, Narapidana, pada hari senin, 30 November 2020
}

dalam masa Covid-19 meskipun diadakannya isolasi terhadap anak dan Narapidana yang baru saja melakukan persalinan. Serta jaminan kebutuhan perlengkapan bayi yang kurang lengkap di LPP.

Untuk sebagian Narapidana yang telah melakukan persalinan, diantaranya terdapat Narapidan yang membawa anaknya ke pihak LPP. Untuk peraturan anak dalam LPP, dia mendapat makanan tambahan sesuai dengan petunjuk dokter sampai anak tersebut menginjak usia 2 tahun. Namun dari pihak LPP tidak menyediakannya, serta keperluan lain seperti susu dan pempers bayi ditanggung sendiri oleh Narapidana yang setatusnya sebagai Ibu dari anak tersebut. Setelah anak sudah berumur 2 tahun, maka anak akan diserahkan kepada pihak keluarga sesuai dengan peraturan pemerintah Nomor 32 Tahun 1999 tentang Syarat dan Tata Cara Pelaksanaan Hak Warga Binaan Pemasyarakatan. ${ }^{49}$

Berdasarkan Undang-Undang Pemasyarakatan dalam pasal 14 ayat 1 huruf (b) tentang mendapatkan perawatan jasmani dan rohani sekaligus mendapatkan fasilitas yang layak yaitu tempat khusus (kamar) yang diberikan kepada Narapidana wanita hamil atau anak dari Narapidana. Akan tetapi untuk penempatan anak di LPP Kelas II B Jambi pada saat ini belum disediakan kamar khusus dan masih bergabung dengan Narapidana lainnya. Dalam masa Covid-19 saat ini untuk menghindari adanya virus-virus maka anak harus diisolasi bersama dengan Ibunya.

\section{Faktor Penghambat Pembinaan Terhadap Narapidana Wanita Hamil di Lapas Perempuan Kelas II B Jambi}

Berdasarkan hasil wawancara bersama dengan Ibu Kurniati, S.H.I selaku bidang Tata Usaha, bahwa:

\begin{abstract}
"Pembinaan yang diberikan oleh petugas LPP terhadap Narapidana wanita hamil pada umumnya sudah layak, namun jika berbicara mengenai hambatan tentunya pasti ada, terutama dalam hal kurangnya fasilitas. Akan tetapi, tentunya para petugas di LPP akan mencari jalan keluar dari adanya hambatan tersebut". ${ }^{50}$
\end{abstract}

Dalam suatu proses, salah satunya proses dalam pembinaan sudah menjadi hal yang wajar jika didalamnya terdapat hambatan-hambatan. Adapun faktor penghambat yang dihadapi oleh petugas LPP Kelas II B Jambi dalam melaksanakan pembinaan terhadap Narapidana wanita hamil, yaitu :

1. Kurangnya Sarana Prasarana dari Bidang Kesehatan

${ }^{49}$ peraturan pemerintah Nomor 32 Tahun 1999 tentang Syarat dan Tata Cara Pelaksanaan Hak Warga Binaan Pemasyarakatan, pasal 20

50 Hasil wawancara bersama dengan Ibu Kurniati, S.H.I, selaku bidang Tata Usaha, Tanggal 30 November 2020 
Sarana prasarana yang seharusnya disediakan lengkap dari pihak LPP terutama sarana dalam bidang kesehatan, karena sarana tersebut sangat penting untuk jaminan kesehatan para Narapidana. Akan tetapi sangat disayangkan sebagaimana hasil wawancara secara langsung bersama Bapak Adi Setiono selaku bidang kesehatan, pihak LPP Kelas II B Jambi pada saat ini mengenai pembinaan terhadap Narapidana wanita hamil belum sesuai dengan Peraturan Pemerintah Nomor 32 Tahun 1999, karena di LPP Kelas II B Jambi belum menyedikan sarana prasarana dari bidang kesehatan, seperti alat untuk melakukan pemeriksaan kandungan, serta alat untuk melakukan USG. Untuk Narapidana wanita yang hamil alat tersebut sangat dibutuhkan guna untuk mengetahui kondisi bayi didalam kandungan.

2. Tidak Tersedianya Tenaga Kesehatan

Disamping tidak tersedianya sarana dan prasarana kesehatan, untuk tenaga kesehatan seperti perawat, bidan ataupun dokter pribadi dari pihak LPP juga tidak tersedia. ${ }^{51}$ Kesediaan tenaga kedokteran pribadi dari pihak LPP Kelas II B Jambi padahal sangat diperlukan, terutama untuk Narapidana yang dalam keadaan mengandung guna untuk mempermudah Narapidana ketika ingin melakukan pemeriksaan kandungan ataupun yang akan melakukan persalinan secara tiba-tiba, dan tidak perlu untuk membawanya Ke Rumah Sakit diluar.

3. Tidak Tersedia Makanan Tambahan

Selain dari kurangnya fasilitas kesehatan, dan kurangnya persediaan Dokter pribadi dari pihak LPP, faktor hambatan lain dari pembinaan terhadap Narapidana wanita hamil di LPP Kelas II B Jambi, yaitu tidak tersedianya makanan tambahan yang seharusnya diberikan kepada Narapidana wanita yang hamil sesuai dengan Peraturan Pemerintah. Ibu Kurniati, S.H.I selaku Bidang Tata Usaha mengatakan bahwa dalam LPP Kelas II B Jambi memang tidak menyediakan makanan tambahan untuk Narapidana wanita hamil. Pihak LPP memberikan makanan kepada Narapidana wanita hamil sebagaimana menu makanan harian yang diberikan kepada Narapidana pada umumnya. ${ }^{52}$

4. Tidak Tersedianya Kamar Khusus Untuk Narapidana Hamil beserta Anak

Faktor lainnya adalah Tidak tersedianya kamar khusus untuk Narapidana yang hamil serta anak yang dibawa. Seharusnya Narapidana yang hamil dan yang membawa anaknya ke pihak LPP mendapatkan tempat yang khusus (kamar) sehingga tidak bergabung dengan Narapidana lainnya dan anak tetap terjaga. Akan tetapi di LPP Kelas II B Jambi untuk

${ }^{51}$ peraturan pemerintah Nomor 32 Tahun 1999 tentang Syarat dan Tata Cara Pelaksanaan Hak Warga Binaan Pemasyarakatan

52 Wawancara bersama Ibu Kurniati, S.H.I selaku bidang Tata Usaha, pada hari senin, 30 November 2020 saat ini belum menyediakan tempat khusus untuk Narapidana yang hamil serta anak yang dibawa ke LPP.

5. Tidak Tersedinya Makanan Untuk Anak dari Narapidana

Dari segi makanan untuk anak dari Narapidana sesuai dengan peraturan pemerintah Nomor 32 Tahun 1999 tentang Syarat dan Tata Cara Pelaksanaan Hak Warga Binaan Pemasyarakatan, bahwa makanan disediakan dari pihak LPP sampai anak berusia 2 tahun. ${ }^{53}$ Sebagaimana yang dikatakan oleh Bapak Adi Setiono selaku bidang kesehatan untuk makanan anak dari Narapidana di LPP Kelas II B Jambi ditanggung sendiri oleh Ibu dari anak tersebut. Serta kebutuhankebutuhan lain dari anak seperti susu dan pempers yang disediakan di koperasi LPP Kelas II B Jambi. Setelah anak sudah berusia 2 tahun, maka Ibu dari anak tersebut wajib menyerahkan kepada pihak keluarga.

Adanya beberapa hambatan tersebut dikarenakan kurangnya anggaran yang diperoleh pihak LPP untuk memenuhi kebutuhan Narapidana, terutama Narapidana dalam keadaan hamil yang memang banyak memerlukan kebutuhan, serta beberapa fasilitas yang harus dilengkapi.

\section{Upaya Mengatasi Terjadinya Hambatan dalam Pembinaan Terhadap Narapidana Wanita Hamil di Lembaga Pemasyarakatan Perempuan Kelas II B Jambi}

Berdasarkan hasil wawancara yang dilakukan bersama Ibu Kurniati, S.H.I selaku bidang Tata Usaha:

"tentunya sudah menjadi tanggungjawab dari para petugas di LPP Kelas II B Jambi untuk mencari upaya dalam mengatasi terjadinya hambatanhambatan tersebut sehingga pembinaan di LPP tetap berjalan dengan lancar sekalipun tidak sesuai dengan Peraturan Pemerintah dan Undang-Undang Pemasyarakatan". 54

Dari hambatan-hambatan yang ada di LPP Kelas II B Jambi dalam melakukan pembinaan terhadap Narapidana wanita hamil, dapat dipastikan bahwa para petugas sudah menyediakan upaya dalam mengatasi adanya hambatan-hambatan tersebut. Karena sudah jadi tanggungjawab para petugas untuk mencari upaya dalam mengatasinya. Dari berbagai hambatan yang dihadapi oleh petugas LPP Kelas II B Jambi terdapat beberapa upaya yang dapat dilakukan dalam mengatasi adanya hambatan yang terjadi dalam pembinaan terhadap Narapidana wanita hamil, yaitu :

53 peraturan pemerintah Nomor 32 Tahun 1999 tentang Syarat dan Tata Cara Pelaksanaan Hak Warga Binaan Pemasyarakatan, pasal 20

54 Wawancara bersama Ibu Kurniati,S.H.I Selaku bidang Tata Usaha, pada hari senin, 30 November 2020 
1. Melakukan Kerja Sama dengan Berbagai Rumah Sakit

Jika terdapat Narapidana wanita hamil yang ingin melakukan pemeriksaan kandungan atau USG, ataupun Narapidana yang sudah mengeluarkan tandatanda ingin melahirkan seperti air ketuban yang sudah pecah atau tanda lainnya, dikarenakan fasilitas kesehatan di LPP pada saat ini belum lengkap, maka pihak LPP langsung membawa Narapidana ke Rumah Sakit terdekat yang sudah melakukan kerjasama dengan pihak LPP Kelas II B Jambi. Berdasarkan hasil wawancara bersama Ibu Kurniati, S.H.I selaku bidang Tata Usaha, Rumah Sakit yang sudah bekerjasama dengan pihak LPP Kelas II B Jambi yaitu, Rumah Sakit Arifin Ahmad, Rumah Sakit Raden Mataher dan Rumah Sakit Bhayangkara. ${ }^{55}$

2. Mendatangkan Dokter dari Berbagai Rumah Sakit

Pihak LPP Kelas II B Jambi yang biasanya mendatangkan pihak dokter dari luar sebanyak 2 (dua) kali dalam sebulan untuk masuk ke LPP guna untuk melakukan pemeriksaan terhadap Narapidana didalam LPP. Namun selama masa Covid-19 pihak LPP tidak lagi memanggil dokter untuk masuk kedalam LPP, jika terdapat Narapidana yang sakit atau ingin melahirkan maka pihak LPP yang mendatangi Rumah Sakit guna untuk mematuhi portokol kesehatan.

3. Memberikan Makanan yang Cukup Gizi

Upaya selanjutnya yang dapat mengatasai adanya hambatan terhadap pembinaan Narapidana wanita hamil berdasarkan hasil wawancara bersama Bapak Ady Setiono, A.Md.kep selaku bidang kesehatan, yaitu memberikan makanan yang cukup gizi, karena di LPP Kelas II B Jambi tidak menyediakan makanan tambahan untuk Narapidana wanita hamil maka petugas LPP telah menggantikan makanan tambahan dengan memberikan makanan yang cukup gizi dan sesuai dengan kalori kesehatan. ${ }^{56}$ Sehingga Narapidana beserta kandungan tetap sehat. Akan tetapi jika terdapat Narapidana wanita hamil yang membutuhkan, seperti kondisi yang kurang baik serta sistem kekebalan tubuh yang menurun, maka pihak LPP akan memberikan makanan tambahan.

4. Menyediakan Koperasi

Sebagaimana hasil wawancara yang dilakukan dengan Ibu Kurniati, S.H.I selaku bidang Tata Usaha, bahwa didalam LPP Kelas II B Jambi telah menyediakan koperasi yang menjual berbagai kebutuhan Narapidana guna untuk mempermudah Narapidana dalam memenuhi kebutuhanannya. ${ }^{57}$

55 Wawancara bersama Ibu Kusniati, S.H.I selaku bidang Tata Usaha, pada hari senin, 30 November 2020

56 Hasil wawancara bersam Bapak Ady Setiono, A.Md.kep, selaku bidang kesehatan,pada hari senin 30 November 2020

57 Wawancara bersama Ibu Kurniati, S.H.I selaku bidang Tata Usaha, pada hari senin, 30 November 2020
Selain itu, koperasi LPP juga menyediakan kebutuhan-kebutuhan anak yang ada didalamnya, seperti susu atau pempers yang merupakan kebutuhan pokok dari anak tersebut. Disanalah Narapidana menemukan kebutuhan-kebutuhan anak termasuk makanan untuk anak. Karena makanan untuk anak ditanggung sendiri oleh Ibunya. Dengan disediakannya koperasi merupakan cara petugas LPP dalam mengatasi adanya hambatan terhadap pembinaan Narapidana wanita hamil.

5. Menyediakan Tempat yang Masih Bergabung dengan Narapidana Lain

Upaya terakhir dalam mengatasi adanya hambatan berupa tidak disediakannya tempat khusus bagi Narapidana yang hamil beserta anak yang dibawanya, petugas LPP memberikan tempat tidur untuk mereka yang masih bergabung dengan Narapidana lainnya. karena kurangnya dana anggaran untuk pihak LPP menambah kamar khusus bagi Narapidana yang hamil serta anak yang dibawa, dan LPP termasuk Lapas yang baru berdiri. Petugas LPP memperbolehkan anak untuk dibawa kedalam Lapas dan diberikan tempat bersama Ibunya, sesuai dengan Peraturan Pemerintah Nomor 32 Tahun 1999 pasal (20) tentang Syarat dan Tata Cara Pelaksanaan Hak Warga Binaan Pemasyarakatan. ${ }^{58}$

\section{SIMPULAN}

Berdasarkan hasil penelitian dapat penulis simpulkan mengenai pembinaan terhadap Narapidana wanita hamil di LPP Kelas II B Jambi, diantaranya sebagai berikut :

1. Pembinaan terhadap Narapidana wanita hamil di Lembaga Pemasyarakatan Perempuan Kelas II B Jambi tetap disamakan dengan pembinaan Narapidana wanita lain pada umumnya, terdapat dua pembinaan yang diterapkan di LPP Kelas II B Jambi, yaitu :

a. Pembinaan Kepribadian, dan

b. Pembinaan Kemandirian

Narapidana wanita hamil mendapatkan keringanan dari pihak LPP untuk tidak melakukan pekerjaan yang berat-berat seperti rutinitas piket kamar, kegiatan senam disetiap hari sabtu, gotong royong ataupun kegiatan lain yang membahayakan kondisi kandungan ataupun Ibunya. Dapat dikatakan bahwa Pembinaan yang diberikan pihak LPP terhadap Narapidana wanita yang hamil sesuai dengan yang penulis teliti saat ini, untuk pemenuhan hak-haknya belum terpenuhi secara maksimal dikarenakan dari faktor kurangnya dana.

2. Hambatan yang terdapat didalam pelaksanaan pembinaan yang diberikan terhadap Narapidana wanita hamil di LPP Kelas II B Jambi, diantaranya :

58 Peraturan Pemerintah Nomor 32 Tahun 1999 Tentang Syarat dan Tata Cara Pelaksanaan Hak Warga Binaan Pemasyarakatan Pasal 20 
a. Kurangnya sarana prasarana dari bidang kesehatan

b. Tidak tersedianya dokter pribadi dari LPP Kelas II B Jambi

c. Tidak adanya makanan tambahan

d. Tidak tersedianya kamar khusus untuk anak dari Narapidana

e. Tidak tersedianya makanan untuk anak Narapidana

Terjadinya hambatan tersebut dikarenakan kurangnya dana yang diperoleh pihak LPP untuk memenuhi kebutuhan Narapidana, terutama Narapidana dalam keadaan hamil serta kurangnya fasilitas yang harus dilengkapi oleh pihak LPP.

3. Upaya untuk mengatasi adanya hambatan dalam Pembinaan terhadap Narapidana wanita hamil di LPP Kelas II B Jambi, yaitu :

a. Melakukan kerjasama dengan berbagai Rumah Sakit

b. Mendatangkan dokter dari berbagai Rumah Sakit

c. Memberikan makanan yang cukup gizi

d. Menyediakan koperasi

e. Menyediakan tempat yang masih gabung dengan Narapidana

Upaya tersebut yang mempengaruhi proses pembinaan terhadap Narapidana wanita hamil sehingga tetap dapat berjalan dengan lancar meskipun tidak sesuai dengan apa yang terdapat dalam Peraturan Pemerintah pada mestinya.

\section{DAFTAR PUSTAKA}

\section{Literatur}

Dwidja Priyatno, Sistem Pelaksanaan Pidana Penjara di Indonesia, Cetakan ke 3, Bandung : Refika Aditama, 2009

Hamja, Pemberdayaan Lembaga Pemasyarakatan Terbuka Sebagai Wujud Pelaksanaan Comunity Based Corbections di Dalam Sistem Peradilan Pidana Indonesia, Yogyakarta : CV Budi Utama, 2015

I Dewa Geda Atmaja dan I Nyoman Putu Budiartha, Teori-teori Hukum, Malang : Setara Press, 2018

Ishaq, Metode Penelitian Hukum dan Penulisan Skripsi, Tesis, Serta Disertasi, Cetakan ke 1, Bandung : Alfabeta, 2017

Leden Marpaung, Asas, Teori, Praktik Hukum Pidana, Cet ke-3 Jakarta : Sinar Grafika, 2006

Lexy J. Moleong, Metodologi Penelitian Kualitatif, Cetakan ke 25, Bandung : PT. Remaja Rosdakarya, 2008

Soerjono Soekanto, Faktor-faktor yang mempengaruhi Penegakan Hukum, Jakarta: Rajawali, 1986

Sugiono, Metode Penelitian Kuantitatif, Kualitatif dan $R \& D$, Cetakan ke 22, Bandung : Alfabeta, 2017

\section{Skripsi}

Tirsa D.G Ticoalu, Perlindungan Hukum Pada Narapidana Wanita Hamil di Lembaga
Pemasyarakatan, Mahasiawa Fakultas Hukum Universitas Sam Ratulangi, 2013

Fita Lisani, Pembinaan Terhadap Narapidana Wanita di Lembaga Pemasyarakatan Anak dan Wanita di Muara Bulian Menurut Hukum Pidana Islam, Mahasiswa Fakultas Syari'ah Institut Agama Islam Negri Sultan Thaha Saifuddin Jambi, 2015

Anita Ayu Widyastuti, Implementasi Hak dan Kewajiban Bagi Warga Binaan Wanita Hamil atau Menyusui dalam Menjalani Masa Hukuman di LAPAS Perempuan Kelas IIB Yogyakarta, Universitas Islam Indonesia, 2018

Lily Lastriana Dewi, Pembinaan Narapidana Wanita yang Mempunyai Anak Balita atau dalam Keadaan Mengandung di Lembaga Pemasyarakatan, Universitas Atma Jaya Yogyakarta, fakultas hukum, 2014

\section{Perundang-Undangan}

Undang-Undang RI Nomor 12 Tahun 1995 Tentang Pemasyarakatan

Kitab Undang-Undang Hukum Pidana Pasal 10 Tentang Pidana

Peraturan Pemerintah Nomor 31 Tahun 1999 Tentang Pembinaan dan Pembimbingan Warga Binaan Pemasyarakatan

Peraturan Pemerintah No.32 Tahun 1999 Tentang Syarat dn Tata Cara Pelaksanan Hak Warga Binaan Pemasyarakatan

\section{Lain-lain}

https://www.negarahukum.com,

Lembaga Pemasyarakatan, Terakhir dilihat pada hari kamis, 30 Januari 2020, pukul 21: 43 WIB

Dr-Suprayanto.blogspot.com, Definisi Ibu Hamil, Terakhir dilihat Pada Hari Rabu, 29 Januari 2020, Pukul 14.20 WIB

https://www.researchgat.net, Efektifitas Pelaksanaan Hak-Hak Warga Binaan Perempuan dalam Mewujudkan Tujuan Pemasyarakatan : Study Kasus Rumah Tahanan Kelas II A Jakarta Timur, diakses pada hari selasa, 21 April 2020, Pukul 22:00 WIB

Wawancara bersama Bapak Muryono selaku bidang Registrasi dan Bimkemas, tanggal 30 November 2020

Wawancara bersam Bapak Ady Setiono, A.Md.kep, selaku bidang kesehatan,tanggal 30 November 2020

Wawancara bersama Ibu Kusniati, S.HI selaku bidang Tata Usaha, tanggal 30 November 2020

Wawancara bersama Narapidana yang telah melahirkan, dengan kasus Tipikor, Ibu Novaria, tanggal 30 November 2020 